\title{
Social Distancing Around the Globe: Cultural Correlates of Reduced Mobility
}

Running Title: Culture and Social Distancing

Hohjin $\operatorname{Im}^{1} \&$ Chuansheng Chen ${ }^{1}$

${ }^{1}$ University of California, Irvine

NOTE: This is an unpublished preprint that has not yet undergone peer-review. This preprint is a working paper and thus is subject to changes with ongoing analyses, updates, and reconceptualization of related variables. This preprint is shared to facilitate quick dissemination of preliminary analyses. However, reported findings and interpretations are not final and should not be used to guide policy or practices.

\author{
Author notes. \\ Hohjin Im, Ph.D. Student, email: hohjini@uci.edu \\ Chuansheng Chen, Chancellor's Professor, email: cschen@uci.edu \\ Department of Psychological Science, University of California, Irvine \\ Correspondence concerning this manuscript should be addressed to Hohjin Im, email: \\ hohjini@uci.edu.
}

\section{Conflict of Interest.}

Both the first and second authors declare no conflicts of interest.

\section{Acknowledgements.}

We would like to thank Google LLC for making the anonymized, aggregated data available for the public. 


\title{
Social Distancing Around the Globe: Cultural Correlates of Reduced Mobility
}

\begin{abstract}
While the United States has struggled to keep the spread of COVID-19 at bay, many other countries have significantly stunted the number of new cases. To examine the cultural values underlying adherence to social distancing, this study used global cultural data as well as data from Google's COVID-19 Community Mobility Reports from February 15, 2020 to June 7, 2020 (N = 14,022) across 123 countries. Segmented piece-wise multilevel modeling was used to examine the longitudinal influence of cultural values of uncertainty avoidance, individualism-collectivism, tightness-looseness, and societal level of trust in three distinct time frames: 1) from February 15, 2020 to the country's $100^{\text {th }}$ COVID-19 case, 2 ) the first 30 days after each country's $100^{\text {th }}$ COVID19 case, and 3) from the $31^{\text {st }}$ day after the $100^{\text {th }}$ case to June 7, 2020. Results showed that collectivism promoted quicker mobilization of social distancing behaviors while uncertainty avoidance stunted this mobilization. After the $100^{\text {th }}$ case of COVID-19, high societal level of trust was related to the decline of social distancing behaviors. Interaction effects showed that countries high on uncertainty avoidance, collectivism, and tightness were all quicker to engage in social distancing at the earliest stages of the pandemic but not at the later stages. With the imminent second wave of COVID-19, policy makers and health scholars may explore the efficacy of culturespecific policies, strategies, and social interventions in mobilizing social distancing measures.
\end{abstract}

Keywords: Social distancing, COVID-19, individualism-collectivism, uncertainty avoidance, tightness-looseness, trust 
As of June 30, 2020, more than 10 million positive cases and half a million deaths from COVID-19 have been documented worldwide (Johns Hopkins Coronavirus Resource Center, 2020). As the number of cases around the world continue to grow, the COVID-19 pandemic reigns as one of the worst virus outbreaks in recent history. In the midst of ongoing research and clinical trials for a vaccine, many countries and local governments have opted to rely on traditional public health interventions, such as social distancing, in an attempt to curtail the spread of COVID-19 within their borders. Social distancing has been endorsed by public health experts (Wilder-Smith et al., 2020; Wilder-Smith \& Freedman, 2020) as one way in which the general public may help to stunt the virus's spread. Indeed, reducing human mobility is likely to also reduce chances for human encounters and viral spread of contagion, shedding light on the importance of human behavior in controlling the pandemic (Anderson et al., 2020). While many countries have observed a significant decline in mobility among their populace in the early days of the pandemic (Huynh, 2020), the cognitive strain of being confined to one's residence for an extended period of time has surely drained the psychological resources of many. Indeed, stories of individuals or select groups defying stay-at-home orders to enjoy the arrival of summer (e.g., Guy, 2020) have unfortunately since become ubiquitous on news and social media.

Recent evidence cites several key factors that may underlie people's intentions or tendencies to engage in social distancing and other preventive health behaviors, such as partisanship (Im et al., 2020; Kushner Gadarian et al., 2020), sense of social responsibility (Oosterhoff et al., 2020; Oosterhoff \& Palmer, 2020), and culture (Biddlestone et al., 2020; Huynh, 2020; Van Bavel et al., 2020), among many others. While the sheer mass of empirical studies and descriptive statistics on COVID-19 have allowed researchers to carefully examine the longitudinal nature of variables like partisanship (e.g., CIVIQS, 2020) or social obligation (e.g., Oosterhoff et 
al., 2020; Oosterhoff \& Palmer, 2020), studies of the role of culture on preventive health behaviors have been limited in their unidimensional nature (Biddlestone et al., 2020), cross-sectional analyses (Huynh, 2020), or lack of empirical testing (Van Bavel et al., 2020). Cultural values and orientations have previously been posited to likely be an important determinant in preventing the spread of infectious diseases (Borg, 2014; Gaygisız et al., 2017) and will likely prove important for influencing the way in which a society's citizens adopt and readily welcome novel methods of preventive health behaviors during the COVID-19 pandemic.

Across the globe, we observe anecdotal evidence of cross-national differences in response to COVID-19. While our more Eastern counterparts (e.g., China, South Korea, Taiwan) have been diligent in spearheading the pandemic with strict social measures in the infant stages of the pandemic, some select Western countries (e.g., United States, Sweden) have been admittedly poor in following suit. Several cultural dimensions may help to explain these cross-national differences beyond economic factors.

\section{Collectivism \& Social Distancing}

In more collectivistic cultures, a sense of communal interdependence is more heavily endorsed and valued over individual agency (Hofstede et al., 2010). In these cultures, social norms and dutiful obligations to the collective good commonly supersede the priority of the individual (Hofstede et al., 2010; Markus \& Kitayama, 2010). Such sense of responsibility beyond the agentic self may cue individuals to advocate for the recognition and attention of and adhere to necessary preventive health behaviors. On the contrary, individualistic cultures tend to place greater emphasis on the self (Markus \& Kitayama, 2010), and views the individual as an agent independent from their social ecology (Hofstede et al., 2010). Hence, compared to those developmentally and socially conditioned in collectivistic cultures, those in more individualistic cultures may be less 
driven by a sense of social obligation for the greater good. Indeed, recent evidence suggests that those higher on collectivism reported greater intentions to engage in social distancing (Biddlestone et al., 2020).

\section{Uncertainty Avoidance \& Social Distancing}

Further, another cultural orientation of interest is uncertainty avoidance. Uncertainty avoidance captures the extent to which a society prefers familiarity over uncertainty and their aversion to unknown outcomes (Hofstede et al., 2010). Cultures high on uncertainty avoidance tend to value rules and regulations that provide greater control over future outcomes (Hofstede, 2011; Hofstede et al., 2010). Given the novelty of COVID-19, and the uncertainty associated with the trajectory of the virus, we may expect that societies high on uncertainty avoidance to be more likely to quickly adopt preventive health and social measures to conjure greater certainty and control in the pandemic outcome. While the link between uncertainty avoidance and social distancing behavior remains scant and largely conceptual, a recent documentation of uncertainty avoidance and mobility provides some evidence that greater uncertainty avoidance was related to lower overall mobility in the early stages of the pandemic (Huynh, 2020). However, it is unclear whether uncertainty avoidance will prove vital in the tail-end of the first wave of the COVID-19 pandemic.

\section{Cultural Tightness-Looseness \& Social Distancing}

Closely related to both collectivism and uncertainty avoidance, a society's strictness to norm adherence is conceptually captured by cultural tightness-looseness (Gelfand et al., 2011). Tight cultures (e.g., South Korea, Japan) typically mandate stricter adherence to social norms and condemn deviations from said norms (Gelfand et al., 2011). On the other hand, loose cultures (e.g., United States, United Kingdom) typically are more permissive of deviations and enforce laxer 
social norms (Gelfand et al., 2011; Harrington \& Gelfand, 2014). Because stricter norms and rules may help coordinate collective action, it has been posited by scholars that cultural tightness may be an important facet in the fight against COVID-19 (Van Bavel et al., 2020). Indeed, recent evidence has documented that societies with tighter cultures were more effective at containing the spread of COVID-19 in the early stages of the pandemic (Gelfand et al., 2020). Within the United

States, states that were culturally tighter also observed greater reduction in overall mobility (Im et al., 2020). Thus, we may observe similar trends across the globe for tight cultures.

\section{Societal Trust \& Social Distancing}

Lastly, societal level of trust may be one commonly overlooked cultural doctrine undermining social distancing orders. While trust in institutions amidst the COVID-19 pandemic has been a common topic of scholarly inquiry among researchers (e.g., Kye \& Hwang, 2020; Llewellyn, 2020), it is less clear how general trust towards others may play a role in the adherence to reduced mobility. In other words, if residents of a society generally exhibit greater levels of general trust towards others, this society may be more inclined to believe that others will act responsibly and adhere social norms and guidelines (e.g., staying at home when sick). In societies where distrust for others is rampant, the opposite may be the case whereby one will strictly adhere to safeguarding oneself against viral infection over fears that others will not abide by social sanctions. Indeed, the body of literature on trust posits that a deterioration of trust leads to more risk management behavior (e.g., Earle et al., 2010). However, no study, to the best of our knowledge, has examined the influence of societal trust at the country-level on social distancing behaviors. Examining this relation may provide a first step in our understanding of how social trust may promote or dissuade social distancing as a form of risk management to oneself.

\section{The Present Study \& Analytical Plan}


In the infant stages of each countries' COVID-19 epidemic, many cultures were slow to mobilize social distancing measures (Figure 1). By the end of the first 30 days after the $100^{\text {th }}$ positive case of COVID-19, a large proportion of countries were effective in reducing their mobility by more than $40 \%$. However, as of the writing of this paper, many of these societies are rapidly regressing towards their baseline level of mobility set during pre-COVID-19 times (Figure 1). Existing studies on the role of cultural orientations on social distancing have been crosssectional (Biddlestone et al., 2020) or at single timeframes (Huynh, 2020), preventing us to understand how certain cultural orientations may promote quicker or slower mobilization of social distancing. Thus, further examination of the role of cultural orientations utilizing longitudinal data may help us to better understand how societies respond across the lifespan of a novel pandemic. Based on the rationale provided in preceding sections, we provide an empirical longitudinal examination of social distancing across 123 countries to examine its cultural value correlates.

Due to the asymptotic, quick growth and subsequent linear, slow decline of social distancing across the globe (Figure 2), a piecewise multilevel modeling approach was undertaken to examine three key time frames: (1) from February 15, 2020 to the day before the first day of each country's $100^{\text {th }}$ case, (2) first day of each country's $100^{\text {th }}$ case to 30 days after, and (3) from the $31^{\text {st }}$ day after the $100^{\text {th }}$ case to June 07,2020 . Longitudinal data were analyzed at the country level. Longitudinal social distancing scores by day (i.e., Level 1) were nested within countries (Level 2). 
Figure 1. Social Distancing Scores Across the Globe

Social Distancing Scores on First Day of 100th Case $n=122$ countries

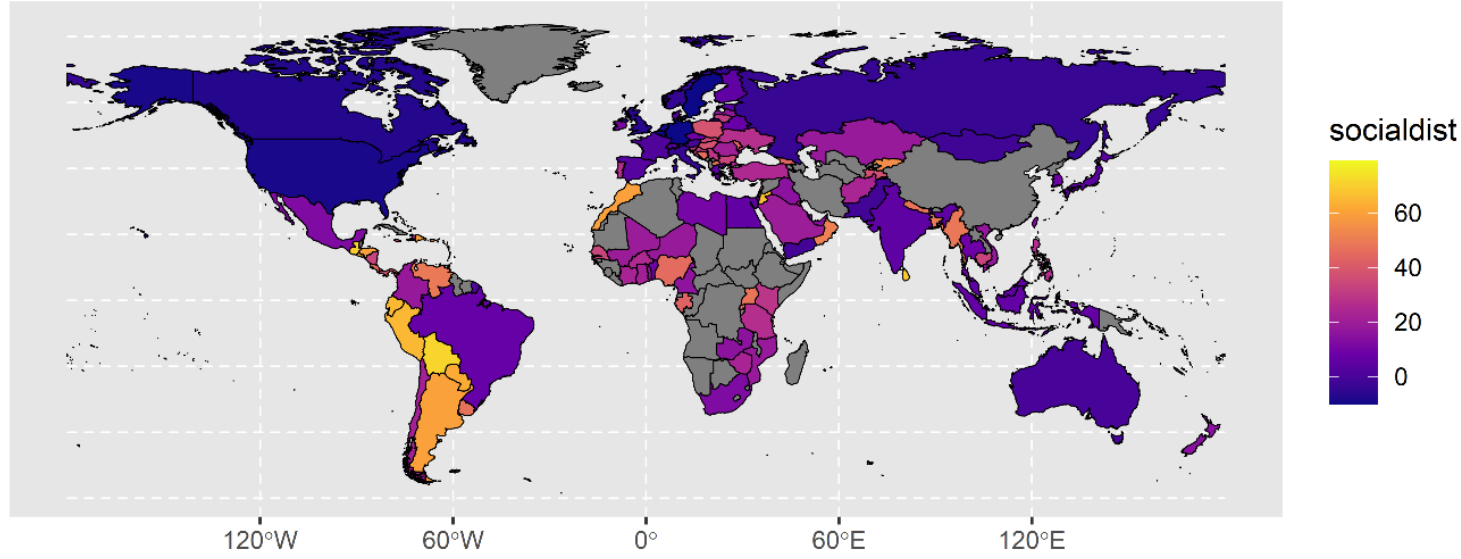

Social Distancing Scores 30 Days after 100th Case $n=115$ countries

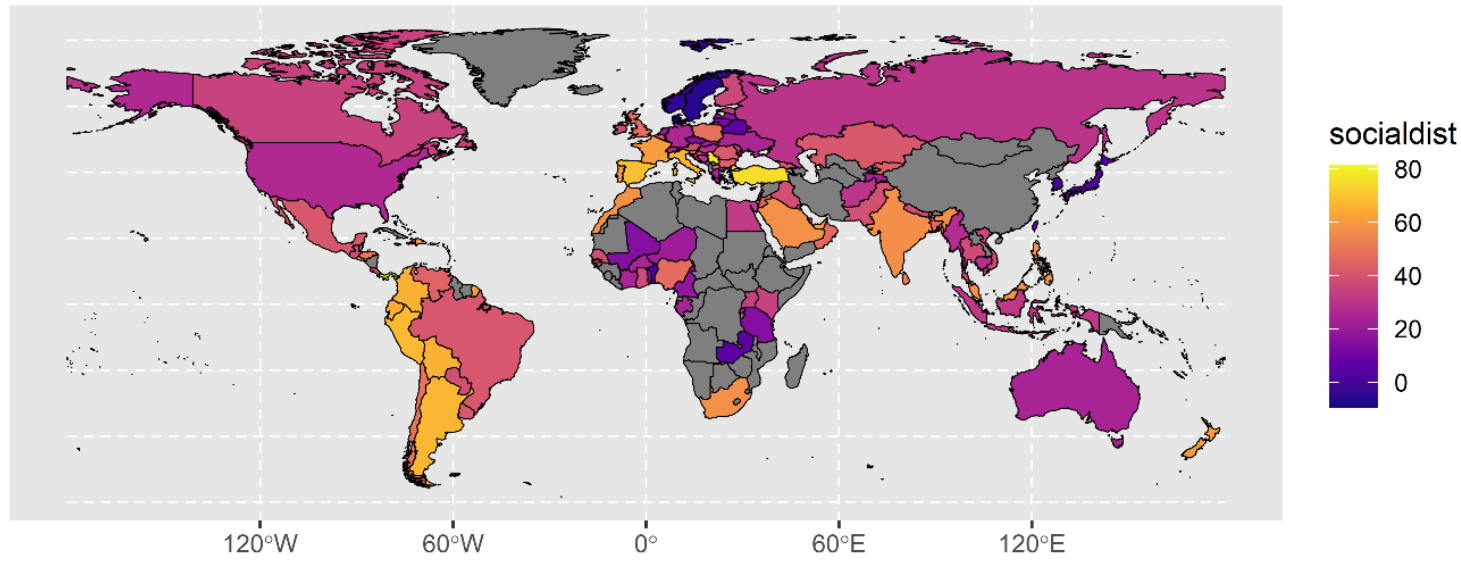

Social distancing Scores on June 7, 2020

$n=122$ countries

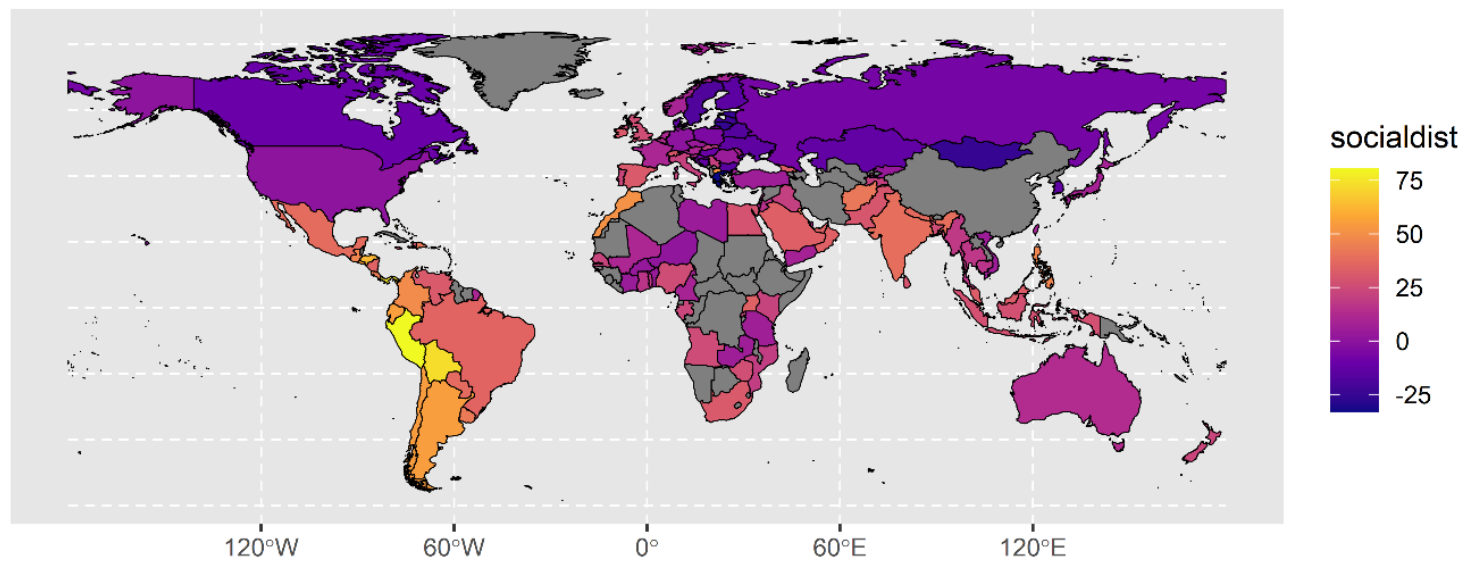


Figure 2. Rise and Decline of Social Distancing by Date

\section{From February 15th to 100th Case of COVID-19}

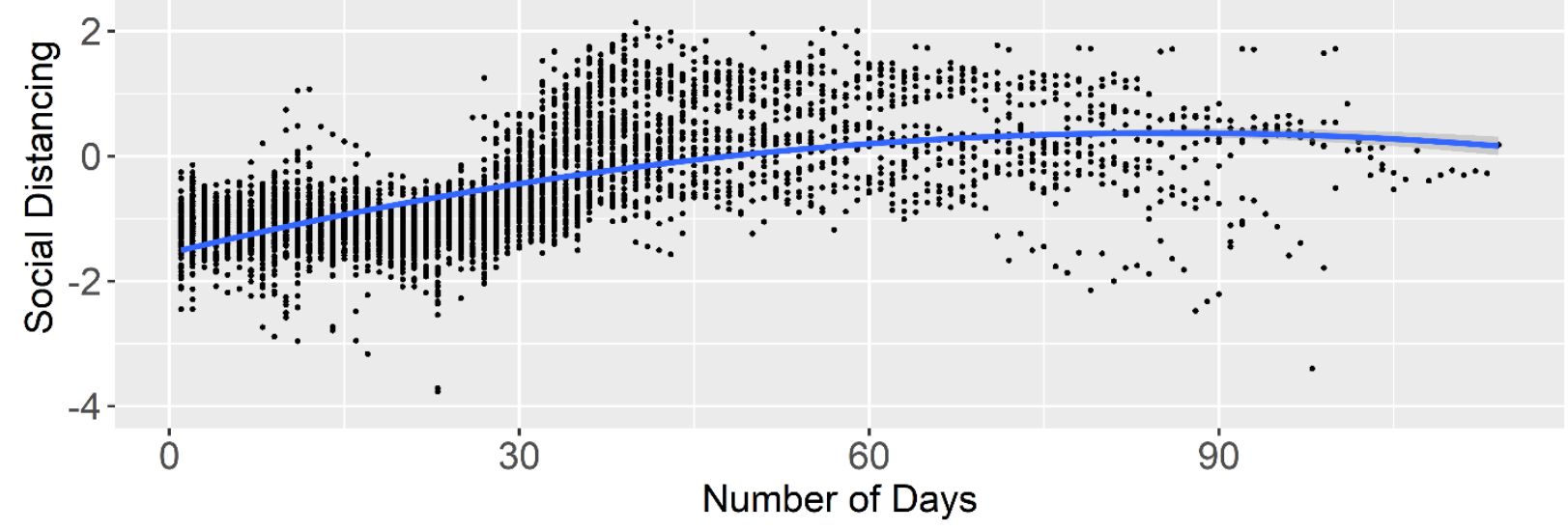

First 30 Days Since 100th Case of COVID-19

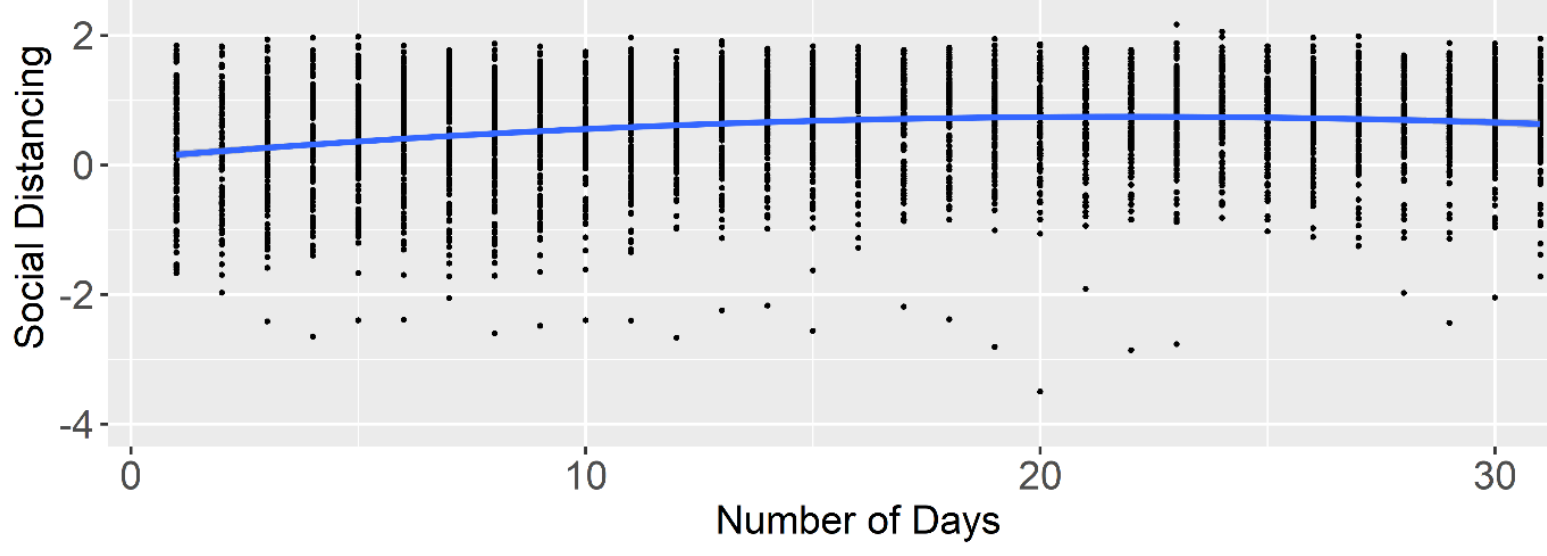

From 30th Day Since 100th Case of COVID-19 to June 7th

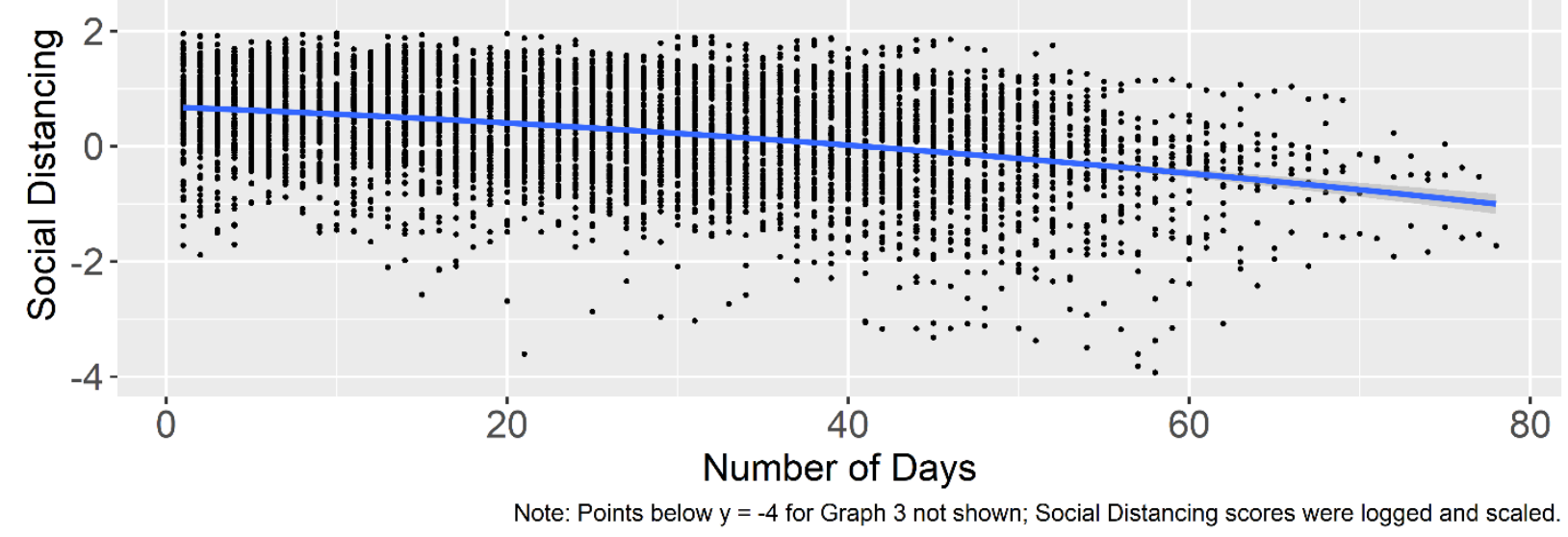




\section{Methods}

\section{Sample}

We rely on publicly available data from Google LLC's COVID-19 Community Mobility Reports (Google LLC, n.d.). Only scores at the country-level were retained due to the research question's objective in examining societal cultural influences and lack of consistent availability of regional data across all countries. We extracted social distancing data from 2020/02/15 to 2020/06/07 for a total of $\mathrm{N}=14,022$ observations across 123 countries around the globe (see Supplemental Materials Table D for list of countries).

\section{Measurements}

Social Distancing. Measures for social distancing and reduction in overall mobility were provided by Google LLC. The anonymized scores for relative reduction in mobility across six dimensions of (1) grocery and pharmacy, (2) local and national park areas, (3) public transport hubs, (4) retail and recreational areas, (5) residence, and (6) the workplace compared to baseline measures of mobility set by pre-COVID-19 times (i.e., the baseline is determined through the median value of the weekday from January 03, 2020 to February 06, 2020). In other words, each daily score is standardized to its respective weekday baseline pre-COVID-19 score. Scores were collected through users who have turned on their mobile device's location history setting. All scores are anonymized and aggregated by Google LLC. Due to the high correlation between residence and workplace mobility (e.g., $r=0.90+$ ), and that many offices and businesses have been shuttered in the wake of the pandemic, the work variable was dropped in this analysis. For specifics on Google LLC's data collection process, please see their data documentation (https://www.google.com/covid19/mobility/data_documentation.html?hl=en\#about-this-data). 
Reliability analyses reveal excellent reliability across the five items, $\alpha=0.897, \omega=0.944$. For ease of analysis, all items were reverse coded except for residence so that higher scores denoted greater social distancing and adherence to shelter-in-place. Due to the initial asymptotic growth, subsequent linear decline of social distancing, and seasonal (by weekday) effects of relative mobility, the composite variable of social distancing was logged and scaled by the day of the week.

Human Development. To control for general economic, educational, and health developments of a country, we relied on the Human Development Index (HDI) provided by the United Nations Developmental Programme (UNDP) (2019). The HDI has three dimensions of (1) Long and Healthy Life, (2) Knowledge, and (3) A Decent Standard of Living to measure general trends for a society's advancements and development in health, education, and economy. Greater scores indicated higher human development for the society. For specifics on UNDP's measurement and calculation process, please refer to their technical documentation (http://hdr.undp.org/en/content/human-development-index-hdi).

Cultural Variables. Hofstede's cultural dimensions (Hofstede et al., 2010) of individualism-collectivism (measured via 6 items) and uncertainty avoidance (measured via 3 items) were included in this study. Individualism-collectivism was reverse coded so that higher scores denoted greater societal collectivism. Hofstede's original analyses included 78 cultures and was later expanded upon by subsequent studies. Scores for additional countries from these subsequent studies were obtained through Hofstede Insights (Hofstede Insights, n.d.). Due to a lack of relation between cultural power distance and social distancing (Huynh, 2020), only collectivism and uncertainty avoidance scores were used in this study. For detailed methodology of the cultural dimensions, please refer to Hofstede et al. (2010). See Appendix Table D for the full list of countries with Hofstede's cultural dimensions. 
Cultural tightness-looseness was captured by the combined domain-specific and domaingeneral scores of cultural looseness as provided by Uz (2015). Uz's (2015) index of cultural tightness-looseness yielded good construct validity in correlation tests. The combined score was reverse coded so that higher scores denote greater cultural tightness. However, given that Uz's (2015) index of tightness-looseness relies different metrics (i.e., tolerance of moral deviations and response variability), we also utilize an extended index of Gelfand et al.'s (2011) cultural tightnesslooseness, as provided by Gelfand et al. (2020) as a conceptual robustness check. Results for these conceptual robustness checks are given in Appendix Tables A-C.

To capture societal trust, we rely on the aggregated single-item score from the World Values Survey across the available six waves of data from 1981 to 2014 (Inglehart et al., 2014). The item asked, "Generally speaking, would you say that most people can be trusted or that you need to be very careful in dealing with people?" The scores of the binary item were aggregated such that they represented the proportion of the population that indicated the level of trust in others.

\section{Results}

Table 1. Bivariate correlations between cultural variables and social distancing score

\section{Timepoints}

\begin{tabular}{lllllll}
\cline { 2 - 6 } Societal Variables & \multicolumn{2}{c}{$\mathbf{1}$} & \multicolumn{2}{c}{$\mathbf{2}$} & \multicolumn{2}{c}{$\mathbf{3}$} \\
\hline Human Development & $-0.323^{* * *}$ & $(118)$ & 0.048 & $(111)$ & $-0.207 *$ & $(118)$ \\
Tightness-Looseness & $0.384 *$ & $(57)$ & -0.014 & $(56)$ & 0.069 & $(57)$ \\
Collectivism & $0.541^{* * *}$ & $(97)$ & $0.236^{*}$ & $(96)$ & $0.364 * * *$ & $(97)$ \\
Uncertainty Avoidance & 0.168 & $(97)$ & $0.245^{*}$ & $(96)$ & -0.058 & $(97)$ \\
Societal Trust & $-0.605 * * *$ & $(88)$ & $-0.445^{* * *}$ & $(85)$ & $-0.353 * * *$ & $(88)$ \\
\hline
\end{tabular}

Note: $* p<0.05, * * p<0.01, * * * p<0.001$; Timepoint 1 = First day country passed $100^{\text {th }}$ case; Timepoint $2=30$ days after country passed $100^{\text {th }}$ case; Timepoint $3=$ June 07,2020 score; sample size (n) given in parentheses.

Table 1 shows the cross-sectional bivariate correlations between social distancing and the cultural variables of interest at select timepoints of (1) the first day the country passed its $100^{\text {th }}$ 
case, (2) 30 days after the country had passed its $100^{\text {th }}$ case, and (3) June 07, 2020. Results indicate that on the first day of each countries' $100^{\text {th }}$ case, tighter and collectivistic societies tend to have already been engaging in more social distancing. On the $30^{\text {th }}$ day after the $100^{\text {th }}$ case, more collectivistic and uncertainty avoidant countries were still engaging in greater social distancing. On the most recent timepoint, more collectivistic societies remained vigilant in engaging in more social distancing. Across all three timepoints, more trusting societies were engaging in less social distancing.

Table 2. Cultural Correlates of Social Distancing from $2020 / 02 / 15$ to first day of $100^{\text {th }}$ case

\begin{tabular}{|c|c|c|c|c|c|c|}
\hline & 1 & 2 & 3 & 4 & 5 & 6 \\
\hline Predictors & $\boldsymbol{\beta}$ & $\boldsymbol{\beta}$ & $\boldsymbol{\beta}$ & $\boldsymbol{\beta}$ & $\boldsymbol{\beta}$ & $\boldsymbol{\beta}$ \\
\hline Intercept & $0.00^{* * *}$ & $0.02^{* * * *}$ & $0.02^{* * * *}$ & $0.01^{* * * *}$ & $-0.01^{* * *}$ & $-0.00^{* * *}$ \\
\hline Time & $0.62^{* * *}$ & $0.50^{* * *}$ & 0.50 & $0.48^{* * * *}$ & $0.46^{* * *}$ & $0.47^{* * *}$ \\
\hline Human Development & -0.06 & 0.11 & 0.07 & 0.12 & 0.13 & 0.12 \\
\hline Uncertainty Avoidance & & $-0.21^{* * *}$ & $-0.17^{* * *}$ & $-0.21^{* * *}$ & $-0.20^{* * *}$ & $-0.20^{* * *}$ \\
\hline Collectivism & & $0.15^{* *}$ & $0.14^{*}$ & 0.17 & $0.17^{\text {** }}$ & $0.17^{* *}$ \\
\hline Tightness-Looseness & & 0.03 & 0.03 & 0.04 & $0.06^{*}$ & 0.03 \\
\hline Societal Trust & & -0.05 & -0.05 & -0.06 & -0.05 & -0.07 \\
\hline Uncertainty Avoid $\times$ Time & & & $0.12^{* * *}$ & & & \\
\hline Collectivism $\times$ Time & & & & $0.06^{*}$ & & \\
\hline Tightness $\times$ Time & & & & & $0.14^{* * *}$ & \\
\hline Trust $\times$ Time & & & & & & $-0.12^{* * *}$ \\
\hline \multicolumn{7}{|l|}{ Random Effects } \\
\hline$\sigma^{2}$ & 0.32 & 0.25 & 0.24 & 0.24 & 0.24 & 0.24 \\
\hline$\tau_{00 \text { country }}$ & 0.07 & 0.03 & 0.03 & 0.03 & 0.03 & 0.03 \\
\hline ICC & 0.19 & 0.10 & 0.11 & 0.10 & 0.10 & 0.10 \\
\hline $\mathrm{N}_{\text {country }}$ & 119 & 51 & 51 & 51 & 51 & 51 \\
\hline Observations & 5052 & 1556 & 1556 & 1556 & 1556 & 1556 \\
\hline $\begin{array}{l}\text { Marginal } \mathrm{R}^{2} / \text { Conditional } \\
\mathrm{R}^{2}\end{array}$ & $0.411 / 0.521$ & $0.288 / 0.358$ & $0.295 / 0.371$ & $0.292 / 0.363$ & $0.307 / 0.376$ & $0.303 / 0.376$ \\
\hline
\end{tabular}

Note: $* p<0.05 * * p<0.01 \quad * * * p<0.001$

Table 2 provides the multilevel model examining the time frame from February 15, 2020 (first day of available data) to the first day of each country's respective $100^{\text {th }}$ case of COVID-19. Progression in time and collectivism were, as expected, significant predictors of increasing social distancing. Surprisingly, uncertainty avoidance was negatively related to progressive engagement 
in social distancing. However, interaction effects reveal that that countries that were higher in uncertainty avoidance, collectivism, and cultural tightness observed quicker mobilization of social distancing behaviors among their populace. On the other hand, cultures that are higher on societal trust are slower to adopt social distancing practices.

Table 3. Cultural Correlates of Social Distancing in the 30 days since the first day of $100^{\text {th }}$ case

\begin{tabular}{|c|c|c|c|c|c|c|}
\hline & 1 & 2 & 3 & 4 & 5 & 6 \\
\hline Predictors & $\boldsymbol{\beta}$ & $\boldsymbol{\beta}$ & $\boldsymbol{\beta}$ & $\boldsymbol{\beta}$ & $\beta$ & $\boldsymbol{\beta}$ \\
\hline Intercept & -0.02 & 0.00 * & $0.00^{*}$ & 0.00 & $0.00^{* * *}$ & $0.00^{*}$ \\
\hline Time & $0.17^{* * *}$ & $0.25^{* * *}$ & $0.25^{* * *}$ & $0.25^{* * *}$ & $0.25^{* * *}$ & $0.25^{* * *}$ \\
\hline Human Development & -0.02 & -0.22 & -0.22 & -0.22 & -0.22 & -0.22 \\
\hline Uncertainty Avoidance & & 0.05 & 0.05 & 0.05 & 0.05 & 0.05 \\
\hline Collectivism & & 0.06 & 0.06 & $0.06^{* *}$ & 0.06 & 0.06 \\
\hline Tightness-Looseness & & -0.15 & -0.15 & -0.15 & -0.14 & -0.15 \\
\hline Societal Trust & & $-0.38^{* * *}$ & $-0.38^{* * *}$ & $-0.38^{* * *}$ & $-0.38^{* * *}$ & $-0.38^{* * *}$ \\
\hline Uncertainty Avoid $\times$ Time & & & -0.00 & & & \\
\hline Collectivism $\times$ Time & & & & $-0.17^{* * *}$ & & \\
\hline Tightness $\times$ Time & & & & & $-0.17^{* * *}$ & \\
\hline Trust $\times$ Time & & & & & & $0.06^{* * *}$ \\
\hline \multicolumn{7}{|l|}{ Random Effects } \\
\hline$\sigma^{2}$ & 0.17 & 0.23 & 0.23 & 0.21 & 0.21 & 0.23 \\
\hline$\tau_{00 \text { country }}$ & 0.44 & 0.22 & 0.22 & 0.22 & 0.22 & 0.22 \\
\hline ICC & 0.72 & 0.49 & 0.49 & 0.51 & 0.51 & 0.49 \\
\hline $\mathrm{N}_{\text {country }}$ & 118 & 51 & 51 & 51 & 51 & 51 \\
\hline Observations & 3559 & 1579 & 1579 & 1579 & 1579 & 1579 \\
\hline $\begin{array}{l}\text { Marginal } \mathrm{R}^{2} \text { / Conditional } \\
\mathrm{R}^{2}\end{array}$ & $0.027 / 0.725$ & $0.317 / 0.652$ & $0.317 / 0.652$ & $0.345 / 0.681$ & $0.346 / 0.681$ & $0.320 / 0.655$ \\
\hline
\end{tabular}

The multilevel model for the time frame of the first 30 days since the first day of each country's $100^{\text {th }}$ case of COVID-19 is given in Table 3. As expected, progression in time continues to be a significant predictor of engagement in social distancing whereas societal trust also remains a robust predictor of decline in social distancing. Results also indicate that after the initial incline in social distancing as observed prior to the countries' $100^{\text {th }}$ case, we see that more collectivistic and culturally tight societies are slower to increase engagement in social distancing. On the other 
hand, societies on the higher end of trust are quicker to adopt social distancing compared to those on the lower tail of trust.

Table 4. Cultural Correlates of Social Distancing from the $30^{\text {th }}$ day since the first $100^{\text {th }}$ case to June 07, 2020.

\begin{tabular}{|c|c|c|c|c|c|c|}
\hline & $\overline{1}$ & 2 & $\overline{3}$ & 4 & 5 & $\overline{6}$ \\
\hline Predictors & $\boldsymbol{\beta}$ & $\boldsymbol{\beta}$ & $\boldsymbol{\beta}$ & $\boldsymbol{\beta}$ & $\boldsymbol{\beta}$ & $\boldsymbol{\beta}$ \\
\hline Intercept & -0.04 & -0.05 & -0.05 & $-0.04^{*}$ & -0.04 & -0.04 \\
\hline Time & $-0.36^{* * *}$ & $-0.38^{* * *}$ & $-0.38^{* * *}$ & $-0.37^{* * *}$ & $-0.38^{* * *}$ & $-0.38^{* * *}$ \\
\hline Human Development & 0.05 & -0.06 & -0.06 & -0.09 & -0.08 & -0.06 \\
\hline Uncertainty Avoidance & & -0.12 & -0.12 & -0.11 & -0.12 & -0.12 \\
\hline Collectivism & & 0.08 & 0.08 & 0.08 & 0.07 & 0.08 \\
\hline Tightness-Looseness & & -0.20 & -0.20 & -0.21 & $-0.20^{* *}$ & -0.20 \\
\hline Societal Trust & & $-0.38^{* *}$ & $-0.38^{* *}$ & $-0.38^{* *}$ & $-0.39^{* *}$ & $-0.38^{* *}$ \\
\hline Uncertainty Avoid $\times$ Time & & & $-0.02 *$ & & & \\
\hline Collectivism $\times$ Time & & & & $0.10^{* * *}$ & & \\
\hline Tightness $\times$ Time & & & & & $0.08^{* * *}$ & \\
\hline Trust $\times$ Time & & & & & & $-0.03^{*}$ \\
\hline \multicolumn{7}{|l|}{ Random Effects } \\
\hline$\sigma^{2}$ & 0.22 & 0.31 & 0.31 & 0.30 & 0.31 & 0.31 \\
\hline$\tau_{00 \text { country }}$ & 0.56 & 0.53 & 0.53 & 0.53 & 0.53 & 0.53 \\
\hline ICC & 0.72 & 0.63 & 0.63 & 0.64 & 0.63 & 0.63 \\
\hline $\mathrm{N}_{\text {country }}$ & 111 & 51 & 51 & 51 & 51 & 51 \\
\hline Observations & 5160 & 2779 & 2779 & 2779 & 2779 & 2779 \\
\hline $\begin{array}{l}\text { Marginal } \mathrm{R}^{2} \text { / Conditional } \\
\mathrm{R}^{2}\end{array}$ & $0.127 / 0.755$ & $0.303 / 0.741$ & $0.304 / 0.741$ & $0.313 / 0.750$ & $0.308 / 0.746$ & $0.305 / 0.741$ \\
\hline
\end{tabular}

The multilevel model for the third time frame is given in Table 4 . After the $30^{\text {th }}$ day since the first $100^{\text {th }}$ case, time and societal trust remain robust, significant predictors of decline in adherence to social distancing. However, none of the other three cultural variables (i.e., uncertainty avoidance, collectivism, and tightness-looseness) are robustly significant at this stage. In examining the interaction effects, societies higher on uncertainty avoidance and societal trust are slower to observe a temporal decline in social distancing, albeit the effect sizes are small and negligible. On the other hand, societies higher on collectivism and tightness are quicker to observe a temporal decline in social distancing. 


\section{Discussion \& Conclusion}

Our models provide an initial examination at the relation between cultural values and engagement in social distancing. In particular, our models suggest that cultural values may have differential effects on engagement in social distancing depending on the time frame of interest. Uncertainty avoidance and collectivism appear to have more robust roles in the initial mobilization of social distancing behaviors in the earliest stages of responding to a pandemic. This is at least partly in line with prior findings of uncertainty avoidance being a key cultural correlate of reducing objective mobility during the first quarter of 2020 (Huynh, 2020). On the other hand, societal level of trust appears to be the most robust indicator of resistance to engaging in and subsequent decline of social distancing behavior after this early stage, partly in line with the body of literature on trust and risk management (e.g., Earle et al., 2010).

Bivariate correlations provide an interesting supplement to the longitudinal examination of select time frames. Namely, on the first day of each countries' $100^{\text {th }}$ case of COVID-19, we observe from bivariate correlations that countries higher on cultural tightness and collectivism also report much greater engagement in social distancing, in line with prior evidence that both tightness and collectivism may be key variables for controlling the spread of infectious diseases (Biddlestone et al., 2020; Gelfand et al., 2020). This may explain anecdotal evidence of East Asian countries that typically rank rather high on collectivism and/or tightness (e.g., China, South Korea, Japan, Taiwan) having all exhibited efficiency in mobilizing collective public adherence to social distancing measures and implementing strict initiatives to contain the virus. On the other hand, more individualistic countries (e.g., United States, Sweden) have admittedly struggled to contain the virus and promote consistent engagement in social distancing protocols amongst their citizens past the peak of the first wave of the pandemic curve. 
While we observe that uncertainty avoidance, collectivism, and cultural tightness all significantly interacted with time, such that countries high on those dimensions were quicker to reduce mobility, we see the opposite effect in subsequent time frames. Indeed, within the secondand third-time frames, we see that collectivism and cultural tightness stunted increases in social distancing and hastened the loosening of such behaviors. This trend is likely explained by the extent to which countries high on these dimensions saw much greater adherence to social distancing measures. That is, because many of these countries were quicker to reduce mobility in the early stages of the pandemic, as well as objectively doing so to a greater extent, these same countries may be quicker to loosen social distancing as they are at different stages of the pandemic curve and regressing towards pre-COVID-19 times lending to a possible fatigue of social distancing.

In the second and third timeframes, we observe that countries that generally report high level of trust for others report significantly less engagement in social distancing across all three timepoints. This is generally robust across bi-variate correlations and longitudinal results. Indeed, trust and confidence are crucial to navigating risk and uncertainty (Earle et al., 2010). With lower trust towards others, one's risk management tendencies may manifest as preventive health behaviors in a precautionary effort to guard oneself in an environment where others cannot be trusted to do the same. Among all the cultural variables, societal trust proved to be the most robust variable within the second and third timeframes. Future studies may seek to examine the specific mechanisms of how trust and risk management may ultimately increase preventive health behaviors.

While the current examination of country-level cultural values is preliminary, it provides insight into how certain values may be key targets of interest for subsequent social interventions. 
Given that a second wave of COVID-19 is likely imminent, and societal values are difficult to change, policy makers may need to become aware of their roles with respect to the sociocultural ecology. Culture-specific strategies, policies, and social interventions may prove fruitful in quickly and effectively mobilizing societies in preparation to engage in what may be an inevitable second round of intensive social distancing and home quarantining. Health policy makers and scholars may benefit from examining and testing the efficacy of appealing to values related to norm adherence (i.e., tightness), interdependence (i.e., collectivism), and minimizing uncertainty (i.e., uncertainty avoidance) in the early stages of a pandemic. Early mobilization in taking preventive health behaviors may be crucial to flatten the curve effectively.

Future research may also investigate effective ways to endorse cautiousness and the importance of engaging in preventive health behaviors while being careful to not spread mistrust and suspicion amongst its populace. Because not many countries had available data across all cultural variables of interest, this limited our sample of countries in models 2-6 of the multilevel analyses. Notably, the countries included in this study generally rank higher on economic and developmental factors than the rest of the world. Thus, it will be necessarily to reanalyze the role of cultural dimensions and orientations on global social distancing behavior as more data becomes available over the lifespan of the pandemic. Further, because the models are at the country-level, it would prove fruitful for future studies to confirm and validate the relations observed in this paper at the micro level. Lastly, similar analyses utilizing alternative measures of cultural dimensions may provide evidence of conceptual robustness. We provide an initial conceptual robustness check utilizing another index of cultural tightness-looseness provided by Gelfand and colleagues (Gelfand et al., 2020) in the Supplementary Materials (see Tables A-C). 
As the virus continues to spread, with many countries and local counties observing new spikes in cases of COVID-19, possibly signaling the arrival of a second wave, discussions about reinstating strict social distancing measures is likely inevitable. For many societies, the public health administration oversees the dissemination of vital information and recommendations for its citizens. Tailoring messages in a manner that caters to the socio-cultural ecology may prove vital for quickly tackling any surges and preventing unnecessary additions to the ever-increasing death count.

\section{Conflict of Interest/Disclosure}

The authors have declared no conflicts of interest. No source of funding was available for this study.

\section{References}

Anderson, R. M., Heesterbeek, H., Klinkenberg, D., \& Hollingsworth, T. D. (2020). How will country-based mitigation measures influence the course of the COVID-19 epidemic? The Lancet, 395(10228), 931-934. https://doi.org/10.1016/S0140-6736(20)30567-5

Biddlestone, M., Green, R., \& Douglas, K. (2020). Cultural orientation, powerlessness, belief in conspiracy theories, and intentions to reduce the spread of COVID-19. British Journal of Social Psychology, Ahead-of-print(Ahead-of-print). https://kar.kent.ac.uk/81621/

Borg, M. A. (2014). Cultural determinants of infection control behaviour: Understanding drivers and implementing effective change. Journal of Hospital Infection, 86(3), 161-168. https://doi.org/10.1016/j.jhin.2013.12.006

CIVIQS. (2020). Coronavirus: Outbreak concern. https://civiqs.com/results/coronavirus_concern?uncertainty=true $\&$ annotations=true $\&$ zoo mIn=true 
Earle, T. C., Siegrist, M., \& Gutscher, H. (2010). Trust, risk perception and the TCC model of cooperation. In Trust in Risk Management: Uncertainty and Scepticism in the Public Mind (1st ed., pp. 18-66). Routledge. https://doi.org/10.4324/9781849773461

Gaygısız, Ü., Lajunen, T., \& Gaygısız, E. (2017). Socio-economic factors, cultural values, national personality and antibiotics use: A cross-cultural study among European countries. Journal of Infection and Public Health, 10(6), 755-760. https://doi.org/10.1016/j.jiph.2016.11.011

Gelfand, M. J., Jackson, J. C., Pan, X., Nau, D., Dagher, M. M., van Lange, P., \& Chiu, C. (2020). The Importance of Cultural Tightness and Government Efficiency For Understanding COVID-19 Growth and Death Rates [Preprint]. PsyArXiv. https://doi.org/10.31234/osf.io/m7f8a

Gelfand, M. J., Raver, J. L., Nishii, L., Leslie, L. M., Lun, J., Lim, B. C., Duan, L., Almaliach, A., Ang, S., Arnadottir, J., Aycan, Z., Boehnke, K., Boski, P., Cabecinhas, R., Chan, D., Chhokar, J., D’Amato, A., Ferrer, M., Fischlmayr, I. C., ... Yamaguchi, S. (2011). Differences Between Tight and Loose Cultures: A 33-Nation Study. Science, 332(6033), 1100-1104. https://doi.org/10.1126/science.1197754

Google LLC. (n.d.). COVID-19 Community Mobility Report. COVID-19 Community Mobility Report. Retrieved June 20, 2020, from https://www.google.com/covid19/mobility?hl=en Guy, J. (2020, June 26). Major incident declared after thousands flock to UK beaches in sweltering heat. $C N N$. https://www.cnn.com/travel/article/bournemouth-major-incidentbeaches-scli-intl-gbr/index.html 
Harrington, J. R., \& Gelfand, M. J. (2014). Tightness-looseness across the 50 united states. Proceedings of the National Academy of Sciences, 111(22), 7990-7995. https://doi.org/10.1073/pnas.1317937111

Hofstede, G. (2011). Dimensionalizing Cultures: The Hofstede Model in Context. Online Readings in Psychology and Culture, 2(1). https://doi.org/10.9707/2307-0919.1014

Hofstede, G., Hofstede, G. J., \& Minkov, M. (2010). Cultures and Organizations: Software of the Mind, Third Edition. McGraw Hill Professional.

Hofstede Insights. (n.d.). Compare countries. Hofstede Insights. Retrieved June 20, 2020, from https://www.hofstede-insights.com/

Huynh, T. L. D. (2020). Does culture matter social distancing under the COVID-19 pandemic? Safety Science, 130, 104872. https://doi.org/10.1016/j.ssci.2020.104872

Im, H., Ahn, C., Wang, P., \& Chen, C. (2020). An Early Examination: Psychological, Health, and Economic Correlates and Determinants of Social Distancing Amidst COVID-19 [Preprint]. PsyArXiv. https://doi.org/10.31234/osf.io/9ravu

Inglehart, R., Haerpfer, C., Moreno, A., Welzel, C., Kizilova, K., Diez-Medrano, J., Lagos, M., Norris, P., Ponarin, E., \& Puranen, B. (2014). World Values Survey: All RoundsCountry-Pooled Datafile 1981-2014. Madrid: JD Systems Institute. http://www.worldvaluessurvey.org/WVSDocumentationWVL.jsp.

Johns Hopkins Coronavirus Resource Center. (2020). Coronavirus Resource Center. COVID-19 Case Tracker. https://coronavirus.jhu.edu/

Kushner Gadarian, S., Goodman, S. W., \& Pepinsky, T. B. (2020). Partisanship, Health Behavior, and Policy Attitudes in the Early Stages of the COVID-19 Pandemic (SSRN 
Scholarly Paper ID 3562796). Social Science Research Network. https://doi.org/10.2139/ssrn.3562796

Kye, B., \& Hwang, S.-J. (2020). Social trust in the midst of pandemic crisis: Implications from COVID-19 of South Korea. Research in Social Stratification and Mobility, 68, 100523. https://doi.org/10.1016/j.rssm.2020.100523

Llewellyn, S. (2020). Covid-19: How to be careful with trust and expertise on social media. BMJ, 368. https://doi.org/10.1136/bmj.m1160

Markus, H. R., \& Kitayama, S. (2010). Cultures and Selves: A Cycle of Mutual Constitution. Perspectives on Psychological Science, 5(4), 420-430. https://doi.org/10.1177/1745691610375557

Oosterhoff, B., \& Palmer, C. (2020). Psychological Correlates of News Monitoring, Social Distancing, Disinfecting, and Hoarding Behaviors among US Adolescents during the COVID-19 Pandemic [Preprint]. PsyArXiv. https://doi.org/10.31234/osf.io/rpcy4

Oosterhoff, B., palmer, C., Wilson, J., \& Shook, N. (2020). Adolescents' Motivations to Engage in Social Distancing during the COVID-19 Pandemic: Associations with Mental and Social Health [Preprint]. PsyArXiv. https://doi.org/10.31234/osf.io/jd2kq

United Nations Development Programme. (2019). Human Development Index (HDI). Human

Development Reports. http://hdr.undp.org/en/content/human-development-index-hdi Uz, I. (2015). The Index of Cultural Tightness and Looseness Among 68 Countries. Journal of Cross-Cultural Psychology, 46(3), 319-335. https://doi.org/10.1177/0022022114563611 Van Bavel, J. J., Baicker, K., Boggio, P. S., Capraro, V., Cichocka, A., Cikara, M., Crockett, M. J., Crum, A. J., Douglas, K. M., Druckman, J. N., Drury, J., Dube, O., Ellemers, N., Finkel, E. J., Fowler, J. H., Gelfand, M., Han, S., Haslam, S. A., Jetten, J., ... Willer, R. 
(2020). Using social and behavioural science to support COVID-19 pandemic response.

Nature Human Behaviour, 4(5), 460-471. https://doi.org/10.1038/s41562-020-0884-z

Wilder-Smith, A., Chiew, C. J., \& Lee, V. J. (2020). Can we contain the COVID-19 outbreak with the same measures as for SARS? The Lancet Infectious Diseases, S1473309920301298. https://doi.org/10.1016/S1473-3099(20)30129-8

Wilder-Smith, A., \& Freedman, D. O. (2020). Isolation, quarantine, social distancing and community containment: Pivotal role for old-style public health measures in the novel coronavirus (2019-nCoV) outbreak. Journal of Travel Medicine, 27(2).

https://doi.org/10.1093/jtm/taaa020 


\section{Supplementary Materials}

In this analysis, we rely on Gelfand et al.'s (2020) extended measurements for cultural tightnesslooseness as a conceptual robustness check to the findings provided in the main paper. Similar to the main findings, we observe cultural tightness having little bearing in the first timeframe (Table A). However, a notable difference is the negative interaction effect with time, suggesting that countries higher on tightness, as measured by Gelfand and colleagues, are slower to mobilize social distancing. This runs counter to the findings as reported in the main analyses. However, given that cultural tightness was calculated differently between Uz (2015) and Gelfand et al. (2020), subsequent studies may examine how differentiated focus on the aspects of cultural tightness may yield quicker or slower response to social distancing. Nonetheless, we observe generally robust negative direct effects of cultural tightness on social distancing during the second timeframe (Table B). While the effects appear larger using Gelfand's cultural tightness scores than the ones observed in the main analyses, the direction of effects remain consistent. Further, as was observed in the main findings, societal trust appears to be the most robust in the third timeframe while other cultural variables show no significant effects (Table C).

Table A. Cultural Correlates of Social Distancing from $2020 / 02 / 15$ to first day of $100^{\text {th }}$ case (using Gelfand's Tightness)

\begin{tabular}{|c|c|c|c|c|c|c|}
\hline & 1 & 2 & 3 & 4 & 5 & 6 \\
\hline Predictors & $\boldsymbol{\beta}$ & $\boldsymbol{\beta}$ & $\boldsymbol{\beta}$ & $\boldsymbol{\beta}$ & $\boldsymbol{\beta}$ & $\boldsymbol{\beta}$ \\
\hline Intercept & $0.02^{* * *}$ & $0.02^{* * *}$ & $0.02^{* * *}$ & $-0.01^{* * *}$ & $0.02^{* * *}$ & $-0.02^{* * *}$ \\
\hline Time & $0.54^{* * *}$ & $0.43^{* * *}$ & $0.43^{* * *}$ & 0.40 & $0.44^{* * *}$ & $0.39^{* * *}$ \\
\hline Human Development & -0.05 & 0.07 & 0.07 & 0.08 & 0.05 & 0.05 \\
\hline Uncertainty Avoidance & & $-0.25^{* * *}$ & $-0.25^{\text {*** }}$ & $-0.25^{* * *}$ & $-0.25^{* * *}$ & $-0.24^{* * *}$ \\
\hline Collectivism & & $0.25^{* * *}$ & $0.25^{* * *}$ & 0.29 & $0.24^{* * *}$ & $0.28^{* * *}$ \\
\hline Tightness-Looseness & & -0.01 & -0.01 & -0.01 & -0.00 & -0.03 \\
\hline Societal Trust & & -0.02 & -0.02 & -0.02 & -0.02 & $-0.02^{* * *}$ \\
\hline Unc. Avoid $\times$ Time & & & 0.01 & & & \\
\hline Collectivism $\times$ Time & & & & $0.13^{* * *}$ & & \\
\hline Tightness $\times$ Time & & & & & $-0.09^{* * *}$ & \\
\hline Trust $\times$ Time & & & & & & $-0.23^{* * *}$ \\
\hline \multicolumn{7}{|l|}{ Random Effects } \\
\hline$\sigma^{2}$ & 0.21 & 0.21 & 0.21 & 0.21 & 0.21 & 0.20 \\
\hline$\tau_{00 \text { country }}$ & 0.04 & 0.02 & 0.02 & 0.02 & 0.02 & 0.02 \\
\hline ICC & 0.16 & 0.08 & 0.08 & 0.09 & 0.08 & 0.10 \\
\hline $\mathrm{N}_{\text {country }}$ & 51 & 44 & 44 & 44 & 44 & 44 \\
\hline Observations & 1596 & 1274 & 1274 & 1274 & 1274 & 1274 \\
\hline $\begin{array}{l}\text { Marginal } \mathrm{R}^{2} \text { / Conditional } \\
\mathrm{R}^{2}\end{array}$ & $0.305 / 0.416$ & $0.278 / 0.338$ & $0.277 / 0.338$ & $0.295 / 0.361$ & $0.285 / 0.345$ & $0.331 / 0.396$ \\
\hline
\end{tabular}


Table B. Cultural Correlates of Social Distancing in the 30 days since the first day of $100^{\text {th }}$ case (Using Gelfand's Tightness)

\begin{tabular}{|c|c|c|c|c|c|c|}
\hline & $\overline{1}$ & 2 & 3 & 4 & 5 & $\overline{6}$ \\
\hline Predictors & $\beta$ & $\beta$ & $\beta$ & $\boldsymbol{\beta}$ & $\boldsymbol{\beta}$ & $\boldsymbol{\beta}$ \\
\hline Intercept & $-0.00^{*}$ & $0.00^{*}$ & $0.00^{*}$ & 0.00 & $0.00^{*}$ & $0.00^{* *}$ \\
\hline Time & $0.31^{* * *}$ & $0.33^{* * *}$ & $0.33^{* * *}$ & $0.33^{* * *}$ & $0.33^{* * *}$ & $0.33^{\text {*** }}$ \\
\hline Human Development & $-0.22 *$ & $-0.29^{* *}$ & $-0.29^{* *}$ & $-0.29^{* *}$ & $-0.29^{* *}$ & $-0.29^{* *}$ \\
\hline Uncertainty Avoidance & & 0.02 & 0.02 & 0.02 & 0.02 & 0.02 \\
\hline Collectivism & & 0.10 & 0.10 & $0.10^{* * *}$ & 0.10 & 0.10 \\
\hline Tightness-Looseness & & $-0.21^{*}$ & $-0.21^{*}$ & $-0.21^{*}$ & $-0.21^{*}$ & $-0.21^{*}$ \\
\hline Societal Trust & & $-0.30^{* *}$ & $-0.30^{* *}$ & $-0.30^{* *}$ & $-0.30^{* *}$ & $-0.30^{* * *}$ \\
\hline Unc. Avoid $\times$ Time & & & $-0.08^{* * *}$ & & & \\
\hline Collectivism $\times$ Time & & & & $-0.17^{* * *}$ & & \\
\hline Tightness $\times$ Time & & & & & 0.01 & \\
\hline Trust $\times$ Time & & & & & & $0.10^{* * *}$ \\
\hline \multicolumn{7}{|l|}{ Random Effects } \\
\hline$\sigma^{2}$ & 0.21 & 0.22 & 0.22 & 0.20 & 0.22 & 0.22 \\
\hline$\tau_{00 \text { country }}$ & 0.34 & 0.17 & 0.17 & 0.17 & 0.17 & 0.17 \\
\hline ICC & 0.62 & 0.44 & 0.44 & 0.46 & 0.44 & 0.45 \\
\hline $\mathrm{N}_{\text {country }}$ & 51 & 44 & 44 & 44 & 44 & 44 \\
\hline Observations & 1577 & 1364 & 1364 & 1364 & 1364 & 1364 \\
\hline $\begin{array}{l}\text { Marginal } \mathrm{R}^{2} / \text { Conditional } \\
\mathrm{R}^{2}\end{array}$ & $0.139 / 0.674$ & $0.425 / 0.677$ & $0.430 / 0.682$ & $0.452 / 0.705$ & $0.425 / 0.677$ & $0.434 / 0.686$ \\
\hline
\end{tabular}


Table C. Cultural Correlates of Social Distancing from the $30^{\text {th }}$ day since the first $100^{\text {th }}$ case to June 07, 2020 (Using Gelfand's Tightness)

\begin{tabular}{|c|c|c|c|c|c|c|}
\hline & 1 & 2 & 3 & 4 & 5 & 6 \\
\hline Predictors & $\beta$ & $\boldsymbol{\beta}$ & $\boldsymbol{\beta}$ & $\boldsymbol{\beta}$ & $\boldsymbol{\beta}$ & $\boldsymbol{\beta}$ \\
\hline Intercept & -0.01 & -0.03 & -0.03 & -0.02 & -0.03 & -0.02 \\
\hline Time & $-0.37^{* * *}$ & $-0.37^{* * *}$ & $-0.37^{* * *}$ & $-0.37^{* * *}$ & $-0.38^{* * *}$ & $-0.37^{* * *}$ \\
\hline Human Development & -0.08 & 0.02 & 0.02 & 0.01 & 0.00 & 0.02 \\
\hline Uncertainty Avoidance & & -0.17 & -0.17 & -0.17 & -0.17 & -0.17 \\
\hline Collectivism & & 0.09 & 0.09 & 0.09 & 0.08 & 0.09 \\
\hline Tightness-Looseness & & -0.04 & -0.04 & -0.04 & -0.03 & -0.04 \\
\hline Societal Trust & & $-0.39^{* *}$ & $-0.39^{* *}$ & $-0.39^{* *}$ & $-0.39^{* *}$ & $-0.39^{*}$ \\
\hline Unc. Avoid $\times$ Time & & & $-0.04^{* * *}$ & & & \\
\hline Collectivism $\times$ Time & & & & $0.09^{* * *}$ & & \\
\hline Tightness $\times$ Time & & & & & $0.08^{* * *}$ & \\
\hline Trust $\times$ Time & & & & & & $-0.03^{* *}$ \\
\hline \multicolumn{7}{|l|}{ Random Effects } \\
\hline$\sigma^{2}$ & 0.19 & 0.20 & 0.20 & 0.19 & 0.19 & 0.20 \\
\hline$\tau_{00 \text { country }}$ & 0.56 & 0.47 & 0.47 & 0.48 & 0.47 & 0.47 \\
\hline ICC & 0.75 & 0.70 & 0.70 & 0.71 & 0.71 & 0.70 \\
\hline $\mathrm{N}_{\text {country }}$ & 50 & 44 & 44 & 44 & 44 & 44 \\
\hline Observations & 2742 & 2466 & 2466 & 2466 & 2466 & 2466 \\
\hline $\begin{array}{l}\text { Marginal } \mathrm{R}^{2} / \text { Conditional } \\
\mathrm{R}^{2}\end{array}$ & $0.157 / 0.787$ & $0.310 / 0.795$ & $0.313 / 0.797$ & $0.317 / 0.804$ & $0.315 / 0.800$ & $0.312 / 0.796$ \\
\hline
\end{tabular}


Table D. Country data availability

\begin{tabular}{|c|c|c|c|c|c|c|}
\hline Country & HDI & Collect. & $\begin{array}{c}\text { Uncert. } \\
\text { Avoidance }\end{array}$ & $\begin{array}{l}\text { Tightness } \\
\text { (Uz) }\end{array}$ & $\begin{array}{l}\text { Tightness } \\
\text { (Gelfand) }\end{array}$ & Trust \\
\hline Afghanistan & $\mathrm{X}$ & & & & & \\
\hline Angola & $\mathrm{X}$ & $\mathrm{X}$ & $\mathrm{X}$ & & & \\
\hline Argentina & $\mathrm{X}$ & $\mathrm{X}$ & $\mathrm{X}$ & $\mathrm{X}$ & $\mathrm{X}$ & $X$ \\
\hline Australia & $\mathrm{X}$ & $\mathrm{X}$ & $\mathrm{X}$ & & $\mathrm{X}$ & $X$ \\
\hline Austria & $\mathrm{X}$ & $\mathrm{X}$ & $\mathrm{X}$ & $\mathrm{X}$ & $\mathrm{X}$ & $X$ \\
\hline Bahrain & $\mathrm{X}$ & & & & & $X$ \\
\hline Bangladesh & $\mathrm{X}$ & $\mathrm{X}$ & $\mathrm{X}$ & $\mathrm{X}$ & & $X$ \\
\hline Belarus & $\mathrm{X}$ & $\mathrm{X}$ & $\mathrm{X}$ & $\mathrm{X}$ & & $X$ \\
\hline Belgium & $\mathrm{X}$ & $\mathrm{X}$ & $X$ & $\mathrm{X}$ & & $X$ \\
\hline Benin & $\mathrm{X}$ & & & & & \\
\hline Bolivia & $\mathrm{X}$ & $\mathrm{X}$ & $\mathrm{X}$ & & & \\
\hline Bosnia and Herzegovina & $\mathrm{X}$ & $\mathrm{X}$ & $\mathrm{X}$ & $\mathrm{X}$ & $\mathrm{X}$ & \\
\hline Brazil & $\mathrm{X}$ & $\mathrm{X}$ & $\mathrm{X}$ & & $\mathrm{X}$ & $X$ \\
\hline Bulgaria & $\mathrm{X}$ & $\mathrm{X}$ & $X$ & $X$ & & $X$ \\
\hline Burkina Faso & $\mathrm{X}$ & $\mathrm{X}$ & $\mathrm{X}$ & & & $X$ \\
\hline Ivory Coast & $\mathrm{X}$ & & & & $\mathrm{X}$ & \\
\hline Cambodia & $\mathrm{X}$ & & & & & \\
\hline Cameroon & $\mathrm{X}$ & & & & & \\
\hline Canada & $\mathrm{X}$ & $\mathrm{X}$ & $\mathrm{X}$ & $\mathrm{X}$ & $\mathrm{X}$ & $X$ \\
\hline Chile & $\mathrm{X}$ & $\mathrm{X}$ & $\mathrm{X}$ & $\mathrm{X}$ & $\mathrm{X}$ & $X$ \\
\hline Colombia & $\mathrm{X}$ & $\mathrm{X}$ & $X$ & & $\mathrm{X}$ & $X$ \\
\hline Costa Rica & $\mathrm{X}$ & $\mathrm{X}$ & $\mathrm{X}$ & & & \\
\hline Croatia & $\mathrm{X}$ & $\mathrm{X}$ & $\mathrm{X}$ & $\mathrm{X}$ & & $X$ \\
\hline Czechia & $\mathrm{X}$ & $\mathrm{X}$ & $X$ & $X$ & $X$ & $X$ \\
\hline Denmark & $\mathrm{X}$ & $\mathrm{X}$ & $\mathrm{X}$ & $\mathrm{X}$ & & $\mathrm{X}$ \\
\hline Dominican Republic & $\mathrm{X}$ & $\mathrm{X}$ & $\mathrm{X}$ & & & $X$ \\
\hline Ecuador & $\mathrm{X}$ & $\mathrm{X}$ & $\mathrm{X}$ & & $\mathrm{X}$ & $X$ \\
\hline Egypt & $\mathrm{X}$ & $\mathrm{X}$ & $\mathrm{X}$ & $\mathrm{X}$ & & $X$ \\
\hline El Salvador & $\mathrm{X}$ & $\mathrm{X}$ & $\mathrm{X}$ & & & $X$ \\
\hline Estonia & $\mathrm{X}$ & $\mathrm{X}$ & $X$ & $\mathrm{X}$ & $\mathrm{X}$ & $\mathrm{X}$ \\
\hline Finland & $\mathrm{X}$ & $\mathrm{X}$ & $X$ & $X$ & $X$ & $X$ \\
\hline France & $\mathrm{X}$ & $\mathrm{X}$ & $\mathrm{X}$ & $\mathrm{X}$ & & $\mathrm{X}$ \\
\hline Gabon & $\mathrm{X}$ & & & & & \\
\hline Georgia & $\mathrm{X}$ & $\mathrm{X}$ & $\mathrm{X}$ & & & $X$ \\
\hline Germany & $\mathrm{X}$ & $X$ & $X$ & $X$ & $X$ & $X$ \\
\hline Ghana & $\mathrm{X}$ & $\mathrm{X}$ & $X$ & & $X$ & $X$ \\
\hline Greece & $X$ & $X$ & $X$ & $X$ & $X$ & $X$ \\
\hline Guatemala & $\mathrm{X}$ & $X$ & $X$ & & & $X$ \\
\hline Haiti & $\mathrm{X}$ & & & & & \\
\hline Honduras & $X$ & $X$ & $\mathrm{X}$ & & & \\
\hline
\end{tabular}




\begin{tabular}{|c|c|c|c|c|c|c|}
\hline Hungary & $X$ & $X$ & $X$ & $X$ & $X$ & $X$ \\
\hline India & $X$ & $X$ & $\mathrm{X}$ & $X$ & $\mathrm{X}$ & $X$ \\
\hline Indonesia & $\mathrm{X}$ & $X$ & $\mathrm{X}$ & $X$ & $\mathrm{X}$ & $X$ \\
\hline Iraq & $\mathrm{X}$ & $\mathrm{X}$ & $\mathrm{X}$ & & & $X$ \\
\hline Ireland & $\mathrm{X}$ & $\mathrm{X}$ & $\mathrm{X}$ & $X$ & $\mathrm{X}$ & $\mathrm{X}$ \\
\hline Israel & $X$ & $X$ & $X$ & & $X$ & $X$ \\
\hline Italy & $\mathrm{X}$ & $\mathrm{X}$ & $\mathrm{X}$ & $X$ & $\mathrm{X}$ & $X$ \\
\hline Jamaica & $\mathrm{X}$ & $X$ & $\mathrm{X}$ & & & \\
\hline Japan & $\mathrm{X}$ & $\mathrm{X}$ & $\mathrm{X}$ & $X$ & $\mathrm{X}$ & $X$ \\
\hline Jordan & $\mathrm{X}$ & $X$ & $\mathrm{X}$ & $X$ & & $X$ \\
\hline Kazakhstan & $\mathrm{X}$ & $X$ & $\mathrm{X}$ & & $\mathrm{X}$ & $X$ \\
\hline Kenya & $\mathrm{X}$ & $\mathrm{X}$ & $\mathrm{X}$ & & $\mathrm{X}$ & \\
\hline Kuwait & $\mathrm{X}$ & $\mathrm{X}$ & $\mathrm{X}$ & & & $\mathrm{X}$ \\
\hline Kyrgyzstan & $X$ & & & $X$ & & \\
\hline Latvia & $X$ & $X$ & $\mathrm{X}$ & $X$ & $\mathrm{X}$ & $X$ \\
\hline Lebanon & $\mathrm{X}$ & $\mathrm{X}$ & $\mathrm{X}$ & & & $X$ \\
\hline Libya & $\mathrm{X}$ & & & & & $X$ \\
\hline Lithuania & $X$ & $\mathrm{X}$ & $X$ & $\mathrm{X}$ & & $X$ \\
\hline Malaysia & $\mathrm{X}$ & $X$ & $\mathrm{X}$ & & $\mathrm{X}$ & $X$ \\
\hline Mali & $X$ & & & & & $X$ \\
\hline Malta & $\mathrm{X}$ & $\mathrm{X}$ & $\mathrm{X}$ & $\mathrm{X}$ & & $X$ \\
\hline Mauritius & $\mathrm{X}$ & & & & & \\
\hline Mexico & $X$ & $X$ & $\mathrm{X}$ & $X$ & $\mathrm{X}$ & $X$ \\
\hline Moldova & $\mathrm{X}$ & $\mathrm{X}$ & $\mathrm{X}$ & $\mathrm{X}$ & & $X$ \\
\hline Mongolia & $\mathrm{X}$ & & & & & \\
\hline Morocco & $\mathrm{X}$ & $\mathrm{X}$ & $\mathrm{X}$ & & & $X$ \\
\hline Mozambique & $\mathrm{X}$ & $\mathrm{X}$ & $\mathrm{X}$ & & $\mathrm{X}$ & \\
\hline Myanmar (Burma) & $\mathrm{X}$ & & & & & \\
\hline Nepal & $\mathrm{X}$ & $\mathrm{X}$ & $\mathrm{X}$ & & & \\
\hline Netherlands & $\mathrm{X}$ & $\mathrm{X}$ & $\mathrm{X}$ & $\mathrm{X}$ & $\mathrm{X}$ & $\mathrm{X}$ \\
\hline New Zealand & $\mathrm{X}$ & $\mathrm{X}$ & $\mathrm{X}$ & & & $\mathrm{X}$ \\
\hline Nicaragua & $\mathrm{X}$ & & & & & \\
\hline Niger & $\mathrm{X}$ & & & & & \\
\hline Nigeria & $\mathrm{X}$ & $\mathrm{X}$ & $\mathrm{X}$ & $\mathrm{X}$ & $\mathrm{X}$ & $X$ \\
\hline North Macedonia & & $\mathrm{X}$ & $\mathrm{X}$ & $\mathrm{X}$ & & $X$ \\
\hline Oman & $\mathrm{X}$ & & & & & \\
\hline Pakistan & $\mathrm{X}$ & $\mathrm{X}$ & $\mathrm{X}$ & & & $X$ \\
\hline Panama & $\mathrm{X}$ & $\mathrm{X}$ & $\mathrm{X}$ & & & \\
\hline Paraguay & $\mathrm{X}$ & $\mathrm{X}$ & $\mathrm{X}$ & & & \\
\hline Peru & $\mathrm{X}$ & $\mathrm{X}$ & $\mathrm{X}$ & $\mathrm{X}$ & $\mathrm{X}$ & $X$ \\
\hline Philippines & $\mathrm{X}$ & $\mathrm{X}$ & $\mathrm{X}$ & $\mathrm{X}$ & & $\mathrm{X}$ \\
\hline Poland & $\mathrm{X}$ & $\mathrm{X}$ & $\mathrm{X}$ & $\mathrm{X}$ & $\mathrm{X}$ & $X$ \\
\hline Portugal & $\mathrm{X}$ & $\mathrm{X}$ & $\mathrm{X}$ & $\mathrm{X}$ & $\mathrm{X}$ & $X$ \\
\hline Puerto Rico & & $\mathrm{X}$ & $\mathrm{X}$ & & & \\
\hline Qatar & $\mathrm{X}$ & $\mathrm{X}$ & $\mathrm{X}$ & & $\mathrm{X}$ & $\mathrm{X}$ \\
\hline
\end{tabular}




\begin{tabular}{|c|c|c|c|c|c|c|}
\hline Romania & $\mathrm{X}$ & $\mathrm{X}$ & $X$ & $\mathrm{X}$ & & $\mathrm{X}$ \\
\hline Russia & $\mathrm{X}$ & $\mathrm{X}$ & $\mathrm{X}$ & $\mathrm{X}$ & $\mathrm{X}$ & $X$ \\
\hline Rwanda & $\mathrm{X}$ & & & & & $X$ \\
\hline Saudi Arabia & $\mathrm{X}$ & $\mathrm{X}$ & $\mathrm{X}$ & $\mathrm{X}$ & $\mathrm{X}$ & \\
\hline Senegal & $\mathrm{X}$ & $\mathrm{X}$ & $\mathrm{X}$ & & & \\
\hline Serbia & $\mathrm{X}$ & $\mathrm{X}$ & $\mathrm{X}$ & $X$ & & $\mathrm{X}$ \\
\hline Singapore & $\mathrm{X}$ & $\mathrm{X}$ & $\mathrm{X}$ & $\mathrm{X}$ & $\mathrm{X}$ & $X$ \\
\hline Slovakia & $\mathrm{X}$ & $\mathrm{X}$ & $\mathrm{X}$ & $\mathrm{X}$ & $\mathrm{X}$ & $X$ \\
\hline Slovenia & $\mathrm{X}$ & $\mathrm{X}$ & $\mathrm{X}$ & $\mathrm{X}$ & & $\mathrm{X}$ \\
\hline South Africa & $\mathrm{X}$ & $\mathrm{X}$ & $\mathrm{X}$ & $\mathrm{X}$ & & $\mathrm{X}$ \\
\hline South Korea & $\mathrm{X}$ & $\mathrm{X}$ & $\mathrm{X}$ & $\mathrm{X}$ & $\mathrm{X}$ & $X$ \\
\hline Spain & $\mathrm{X}$ & $\mathrm{X}$ & $\mathrm{X}$ & $\mathrm{X}$ & $\mathrm{X}$ & $\mathrm{X}$ \\
\hline Sri Lanka & $\mathrm{X}$ & $\mathrm{X}$ & $\mathrm{X}$ & & $\mathrm{X}$ & \\
\hline Sweden & $\mathrm{X}$ & $\mathrm{X}$ & $\mathrm{X}$ & $X$ & $\mathrm{X}$ & $\mathrm{X}$ \\
\hline Taiwan & & $\mathrm{X}$ & $\mathrm{X}$ & & & $X$ \\
\hline Tajikistan & $\mathrm{X}$ & & & & & \\
\hline Tanzania & $\mathrm{X}$ & $\mathrm{X}$ & $\mathrm{X}$ & $\mathrm{X}$ & & $\mathrm{X}$ \\
\hline Thailand & $\mathrm{X}$ & $\mathrm{X}$ & $\mathrm{X}$ & & $\mathrm{X}$ & $\mathrm{X}$ \\
\hline The Bahamas & $\mathrm{X}$ & & & & & \\
\hline Togo & $X$ & & & & & \\
\hline Trinidad and Tobago & $\mathrm{X}$ & $\mathrm{X}$ & $\mathrm{X}$ & & $\mathrm{X}$ & $\mathrm{X}$ \\
\hline Turkey & $\mathrm{X}$ & $\mathrm{X}$ & $X$ & $\mathrm{X}$ & $\mathrm{X}$ & $X$ \\
\hline Uganda & $\mathrm{X}$ & & & $\mathrm{X}$ & & $X$ \\
\hline Ukraine & $\mathrm{X}$ & $\mathrm{X}$ & $\mathrm{X}$ & $\mathrm{X}$ & $\mathrm{X}$ & $X$ \\
\hline United Arab Emirates & $\mathrm{X}$ & $\mathrm{X}$ & $\mathrm{X}$ & & $\mathrm{X}$ & \\
\hline United Kingdom & $\mathrm{X}$ & $\mathrm{X}$ & $\mathrm{X}$ & & $\mathrm{X}$ & $\mathrm{X}$ \\
\hline United States & $\mathrm{X}$ & $\mathrm{X}$ & $\mathrm{X}$ & $\mathrm{X}$ & $\mathrm{X}$ & $X$ \\
\hline Uruguay & $\mathrm{X}$ & $\mathrm{X}$ & $\mathrm{X}$ & & & $\mathrm{X}$ \\
\hline Venezuela & $\mathrm{X}$ & $\mathrm{X}$ & $\mathrm{X}$ & & & $\mathrm{X}$ \\
\hline Vietnam & $\mathrm{X}$ & $\mathrm{X}$ & $\mathrm{X}$ & $\mathrm{X}$ & $\mathrm{X}$ & $X$ \\
\hline Yemen & $\mathrm{X}$ & & & & & $\mathrm{X}$ \\
\hline Zambia & $\mathrm{X}$ & $\mathrm{X}$ & $\mathrm{X}$ & & & $X$ \\
\hline Zimbabwe & $X$ & & & $X$ & & $\mathrm{X}$ \\
\hline
\end{tabular}

Table D lists the countries for which data was available. All countries had data available for Google LLC's social distancing scores. The source of the data can be found in the following links:

Human Development Index (2018): http://hdr.undp.org/en/data

Google LLC's COVID-19 Mobility Report: https://www.google.com/covid19/mobility/

Hofstede's Cultural Dimension Scores: https://www.hofstede-insights.com/product/comparecountries/ \& https://geerthofstede.com/research-and-vsm/dimension-data-matrix/ World Values Survey Scores: http://www.worldvaluessurvey.org/WVSContents.jsp Tightness-Looseness Scores (Uz): https://doi.org/10.1177/0022022114563611 
Tightness-Looseness Scores (Gelfand): https://osf.io/pc4ef/ 